Review Article

\title{
Shale Oil Exploration from Paleocene-early Eocene Sequence in Cambay Rift Basin, India
}

\author{
P K PADHY*, ARUN KUMAR, Y RAMESH CHANDRA, SHISHIR KUMAR DAS, S K JHA and \\ D R ADVANI \\ COD-Shale Gas, Oil \& Natural Gas Corporation, Vadodara 390 009, Gujarat
}

(Received on 15 May 2016; Accepted on 25 June 2016)

\begin{abstract}
Shale gas and oil constitute an important unconventional resource of hydrocarbons stored in organic rich, matured fine grained sedimentary rock. The organic rich source rock, on deep burial, results in conversion of organic matter into oil and natural gas. A major part of the hydrocarbons is expelled, migrated and entrapped in ideal locales constituting conventional accumulations in the basin. The residual quantities retained within the original source rock constitute the unconventional shale gas and oil plays. The gas and oil in shale are held as free hydrocarbons within natural fractures, pore spaces and some gas are stored as adsorbed gas on the organic matter. The shale, characterized by low matrix permeability, requires hydrofracturing for shale gas and oil production.

A pilot Shale gas and oil well (Well-X) is drilled in Broach-Jambusar block of Cenozoic Cambay Petroliferous basin is drilled and extensive core has been collected in the Cambay Shale section of Paleocene-early Eocene age. Detailed shale specific geological, minerological, geochemical, petrophysical, geomechanical, desorption and adsorption isotherm studies etc are carried out and are synthesized for prospect evaluation. The Cambay Shale is moderately fissile, silty with presence of occasional fractures. The average Total Organic Content (TOC) is around $2.9 \mathrm{wt} \%$. The shale is characterized by high clay (kaolinite and chamosite) content of around 55\% with average quartz content around 29\%.The shale resistivity is $1.5-4.0$ $\mathrm{ohm}-\mathrm{m}$. Based on integrated analysis, a zone of $60 \mathrm{~m}$ was hydrofractured and it yielded oil (API gravity: 40.0). TransgressiveRegressive cycle analysis of the shale section has been attempted for better understanding of the unconventional plays.
\end{abstract}

Keywords: Cambay Basin; Shale Gas and Shale Oil; Cambay Shale; Paleocene-early Eocene; Sequence Stratigraphy; Hydrofracturing

\section{Introduction}

Shale is a fine-grained, fissile, detrital sedimentary rock formed by consolidation of clay (less than 4 micron size). It is composed of fine-grained detrital matrices of silt, clay-sized bits of organic matter, quartz, feldspar, clay minerals, calcite, dolomite and other minerals. Various clay types and their volume influence the quality of the shale reservoir from petrophysical and geomechanical perspective (Atkins et al., 2011). In case of shale gas and oil, shale acts as both source and reservoir rock.

The organic components of the shale are algaeplants and marine organisms. During burial, these organic matters (known as kerogen) cracks to form hydrocarbons. The thermal process causes the organic matter to mature. The left out hydrocarbons could be predominantly either shale oil or shale gas depending on the maturation level of the source rock. The quantities of gas and oil stored in the shale reservoir depends on specific source rock characteristics such as total organic carbon (TOC), thermal maturity and the type of kerogen present. Shale with high gamma (characteristics of rich organic matters), high resistivity, low density, high TOC content (>2-3 wt $\%$ ), high maturation value (Vro>1.2), low water saturation, high Young's modulus and low Poisson's ratio are ideal characteristics, known as "sweet spots" for shale gas exploration. Source rock within moderate thermal maturity (oil window with Vro ranging from

\footnotetext{
*Author for Correspondence: E-mail:padhy_pk@ongc.co.in
} 
0.6-1.2) would yield mainly shale oil.Natural fractures are more prevalent in silica-rich and carbonate-rich shales. The brittleness of the shale with low clay content $(<30 \%)$ is the key factor in carrying out successful hydrofrac jobs.

Government of India, in its effort to boost the shale gas and oil exploration activities, announced the Shale Gas and Oil Policy guidelines in October, 2013 allowing the National Oil Companies (NOCs) to carry out shale gas and oil exploration activities in their nomination blocks. ONGC initiated the shale gas and oil exploration activities in four basins namely, Cambay, Krishna-Godavari, Cauvery and Assam \& Assam Arakan as per the new policy guidelines and drilled the pilot well (Well-X) in Cambay basin in 2013-2014.

A number of Indian sedimentary basins have thick shale sections (source facies) deposited through wide geological time. There has been scope of envisaged shale gas and oil potential in different sedimentary basins of India (Padhy and Naik, 1991; Mishra, 2008; Sharma and Kulkarni, 2010; Kumar et al., 2013; Padhy and Das 2013; Padhy et al., 2013; Padhy, 2016). In comparison to the global shale gas basins, shale of Indian sedimentary basins are rich in organic matter of Type III with minor input of Type II whereas the established shale gas basins of USA and Canada are generally rich in better organic matters like Type I and Type II. In general the geological age of the source facies of Indian sedimentary basins ranges from Permian to Tertiary where as in USA and Canada the established plays are within the older geological sequence (Paleozoic-Mesozoic). Most of the Indian basins are envisaged to be prospective for shale oil as the thermal maturity is around 1.0-1.2. The shales of Indian sedimentary basins are relatively rich in clay and occur at a relatively greater depth.

The potential shale oil resource (USGS, 2013) in Cambay basin is estimated to be $62 \mathrm{MMBO}$. As per the study carried out by Energy Information Administration (EIA) of USA in 2013, the risked recoverable Shale gas in Cambay basin is of the order of $29.5 \mathrm{Tcf}$ and risked recoverable oil is of the order of 2.71 Billion bbl.

In the present paper, the salient studies carried out in the first pilot well, Well-X, in South Cambay basin, has been analysed from the shale oil exploration point of view.

\section{Geologic Setting}

The Cambay Basin is a narrow elongated intracratonic Cenozoic rift basin along NNW-SSE Dharwarian trend, located on the north western part of the Indian craton. The basin is bounded by Kutch-Saurashtra arc in the west and Aravalli-Delhi fold belt in the east. Isolated Mesozoic outcrops are present in the eastern and western part of the basin. The Cambay rift initiated during late Cretaceous time along the Dharwarian orogenic trend during the northward drifting of the Indian plate along counter clockwise path subsequent to initial break up of Indian plate from southern Gondwanaland in late Triassic (Biswas, 1982). The sinusoidal basin propagation with moderate angle and basin bounding listric fault arrays exhibit influence of oblique tensional/trans-tensional dynamics resulting in a typical half graben style of basin geometry (Kundu et al., 1993; Thakre and Padhy, 1993; Padhy and Singh, 1998). The hydrocarbons occur in sequences ranging from Paleocene through Miocene and major accumulations in middle Eocene are associated with structural traps over block uplifts and block edge folds Raju and Srinivasan (1993) and Raju et al. (2005).

The $425 \mathrm{~km}$ long basin narrows towards the distal part (40 km in north and around $100 \mathrm{~km}$ in south) inferring northward diminishment of rift propagation. Tectono-stratigraphically, the basin is divided into South Cambay basin, comprising blocks namely Narmada and Broach-Jambusar blocks and North Cambay basin, comprising of Cambay-Tarapur, Ahmedabad-Mehsana and Patan-Sanchor blocks (Fig. 1). The extensional architecture of the basin is defined by two types of faults viz.listric normal faults, striking N-S to NNW-SSE and 'transfer faults', trending ENE-WSW to NE-SW, often offsetting the listric normal faults. The basin segmentation is characterized by presence of orthogonal compartmental cross strike faults/conjugate transfer zones across rift tract. Repeated movements, probably in varying senses (extensional, locally compressional and strike-slip), have given rise to relatively low amplitude basin inversion.

The break-up of Seychelles from India at the K-T boundary resulted large scale volcanic activities during late Cretaceous. In the early synrift, the basalt derived materials constitutes Olpad formation deposited under fluvial environment during Paleocene 


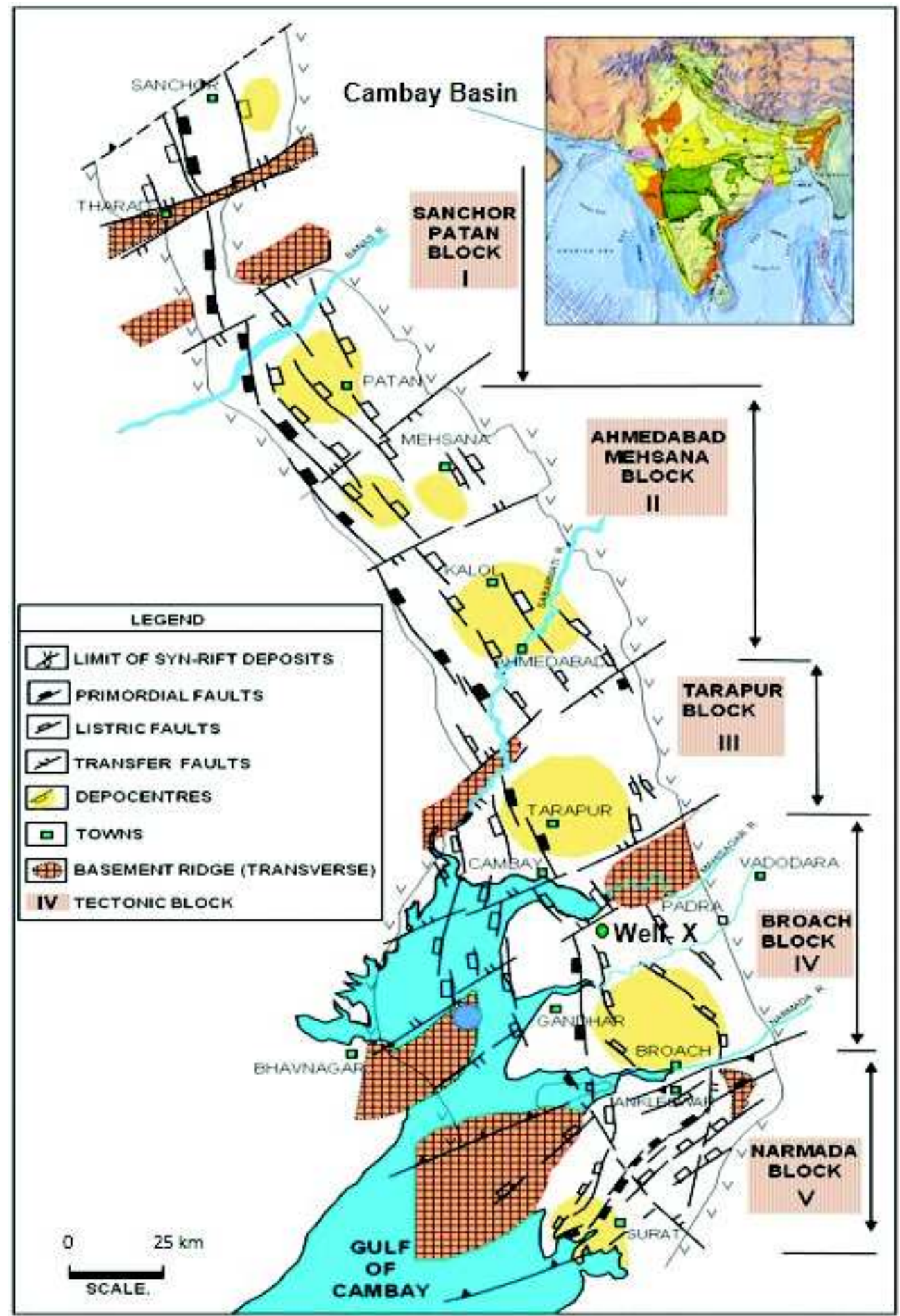

Fig. 1: Tectonic map of Cambay basin (Kundu et al., 1993). The Shale gas and oil well, Well- X, falls in Broach block, South Cambay basin

time. The early rift stage was succeeded by subsidence and with marine transgression depositing Cambay Shale (Paleocene-early Eocene age) as principal source facies (Fig. 2).
At a later stage, the homo-taxial transgressive phase equivalent of Younger Cambay Shale of South Cambay Basin is characterized by the development of three hydrocarbon bearing regressive units known 


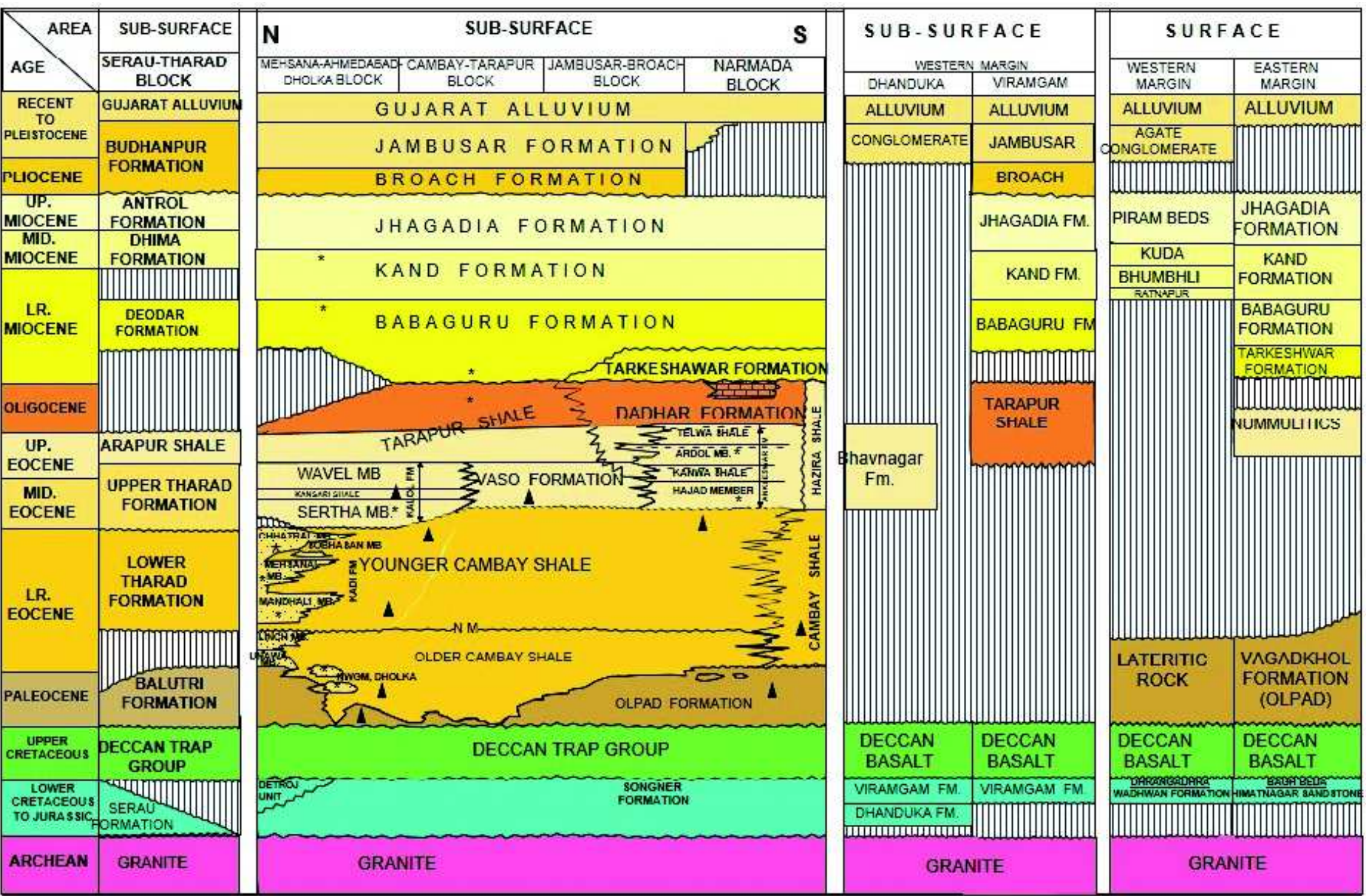

Fig. 2: Stratigraphy of Cambay basin. Surface and subsurface equivalents of western margin and eastern margin have also been depicted 
as Mandhali, Mehsana and Chhatral members of Kadi formation in the northern part of the Cambay basin. The Cambay-Tarapur block is characterised by poor influx of coarser clastics during middle Eocene time.

Extensive hydro-carbon bearing middle Eocene sediments (Ankleswar formation in South Cambay Basin and Kalol formation in the north Cambay basin) were deposited in the basin during post rift phase. Basin scale transgression prevailed during late Eocene to early Oligocene, in conformity with global rise in sea level, depositing Tarapur Shale which constitutes the regional cap rock. During late Miocene (late post rift phase), the basin experienced mild inversion tectonics related to the Himalayan Orogeny and the basin is characterized by deposition of shallow marine to continental sediments. Broadly the basin witnessed fluvial-inner-mid shelf depositional setting in its evolution. The hydrocarbon migration occurred during early Miocene coinciding with the post-terminal phase of the basin inversion.

\section{Cambay Shale Geology of Broach-Jambusar Block}

The block is bounded by transverse fault along Mahisagar river in the north and Narmada fault in the south (Fig. 1). The morphotectonic assemblages with structural uplifts, Devla-Malpur in the north and Dahej, Aliabet in the south with intervening depressions at centre are manifestation of structural movement along the block bound faults. Many hydrocarbon fields namely Gandhar, Nada, Dabka, Gajera, Dahej, Pakhajan, Padra etc have been discovered in this block. The depression is an oval shaped filled with deposition of the Tertiary sediments with thickness to the tune of approximately $5.0 \mathrm{~km}$ in the deepest part of the basin.

The Cambay Shale thickness ranges from 500 $\mathrm{m}$ in the flank to more than $1000 \mathrm{~m}$ towards depocentre (Fig. 3). The early Tertiary sediments ranging in age from Paleocene to early Eocene represent the syn-rift stage of deposition. The synrift phase during Paleocene witnessed deposition of trap derivative materials (Olpad) followed by basin subsidence. Top of Paleocene (55.8 Ma) is marked by an unconformity. The basin witnessed transgression resulting deposition of thick dark grey, organic shale sequence known as Cambay Shale through Paleocene to early Eocene (48.6 Ma). The Cambay Shale overlies the Olpad of the Paleocene age and is unconformably underlain by the Middle Eocene Hazad member. Cambay Shale can be broadly lithostratigraphically classified into Older and Younger members (Fig. 2). The 'Y-Marker' towards the late part of early Eocene is often characterized by medium to fine grained sandstone with thin lamination of shale and occasionally thin coal bed and separates Older Cambay Shale (OCS) below and Younger Cambay Shale (YCS) above it. Cambay Shale (Paleocene to early Eocene age) has mostly conformable to gradational and inter-tonguing relationship with the underlying Olpad formation but at places it also exhibits an unconformable contact. The Older Cambay Shale comprises of grey to dark grey, moderately fissile with minor siltstone. Shale is occasionally calcareous, at times carbonaceous.Occasional presence of pyrite is often seen. The Younger Cambay Shale (YCS) member, overlying the Older Cambay Shale (OCS) member, comprises of grey to black, massive, sideritic and carbonaceous shale along with thin silt bands. Presence of pyrite is also observed at some place. Petrographically the shale lithology of Cambay Shale section is classified as tight, moderately laminated carbonaceous shale having clay rich matrix. The Cambay Shale is deposited in marginal marine (subtidal to coastal-shoreface) environment. Occasional sideritic nodules are often found indicating oxic depositional condition.

Presence of pyrite above Y-marker infers anoxic condition. The upper part of Cambay Shale (approximately 50m above and below Y-Marker) is characterized by high uranium content and it decreases rapidly down below. The high uranium content is attributed to more of transitional to marine affinity of depositional condition.

Average total organic carbon (TOC) values in Broach-Jambusar Block varies from 1 to $3 \mathrm{wt} \%$, and the value is more (around 4-5wt\%) in the north Cambay basin (Fig. 4). Vitrinite value is more (around 1.2) in the south Cambay basin and it is less (around 0.8 ) in the north Cambay basin (Fig. 5). It is envisaged to be higher towards deeper part of the depocentres.

The Broach-Jambusar block experiences at places marginally high pressure and towards northwest in Nada area high pressure has been observed. The geothermal gradient is of the order of 3.0 to $3.5 \mathrm{deg} . / 100 \mathrm{~m}$. 


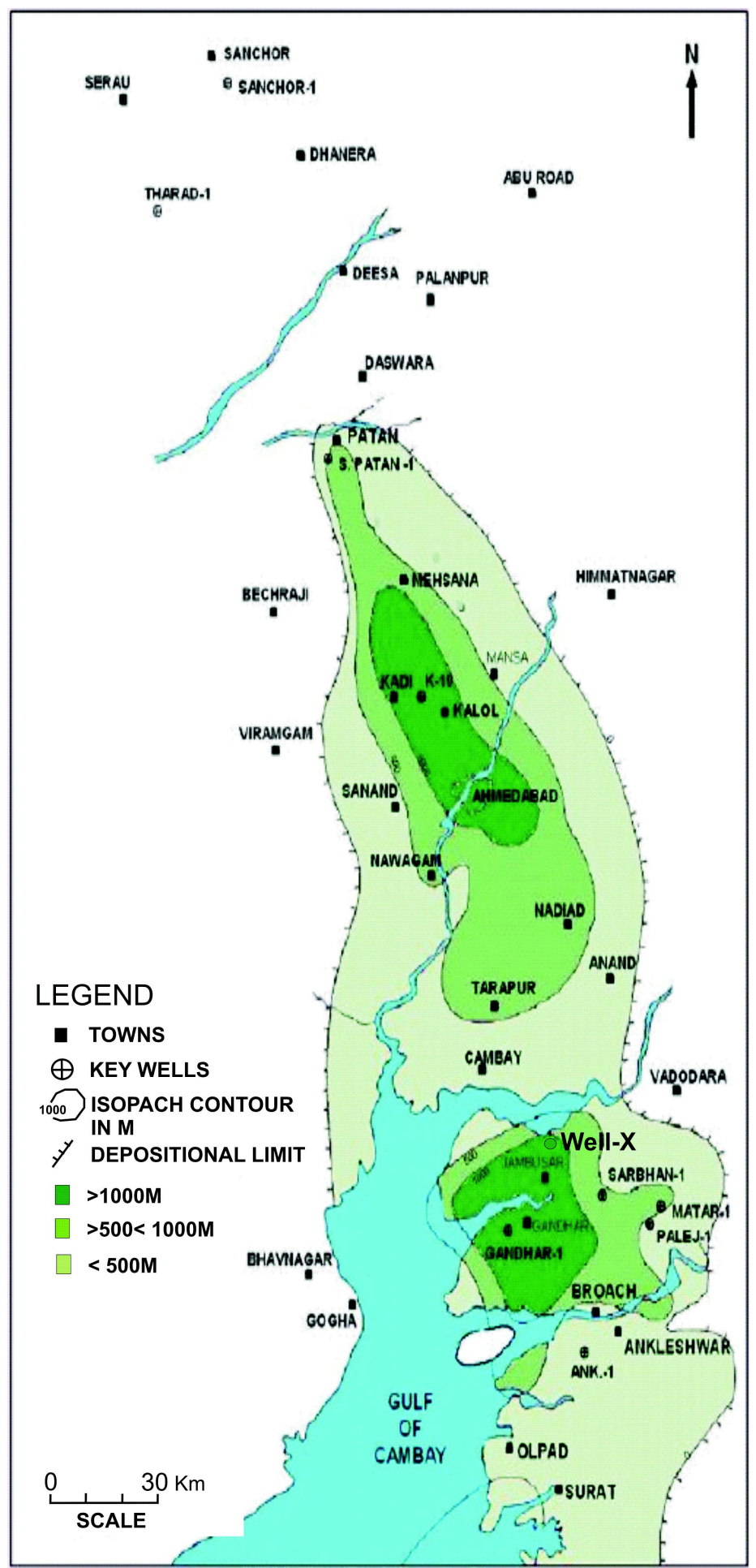

Fig. 3: Isopach Map of Cambay Shale. More than $1000 \mathrm{~m}$ of Cambay Shale has been deposited in the depocentres. Broach is the deepest depocentre

Source Potential of Cambay Shale in BroachJambusar Block

The Cambay Shale is the main source facies in Cambay basin. The kerogen is predominantly Type
III with some contribution from Type II organic matter. Thermal maturity in Cambay Shale, in most parts of the depression (excluding areas close to basin margin), is within oil window i.e. $>0.6 \%$ and varies in range of 


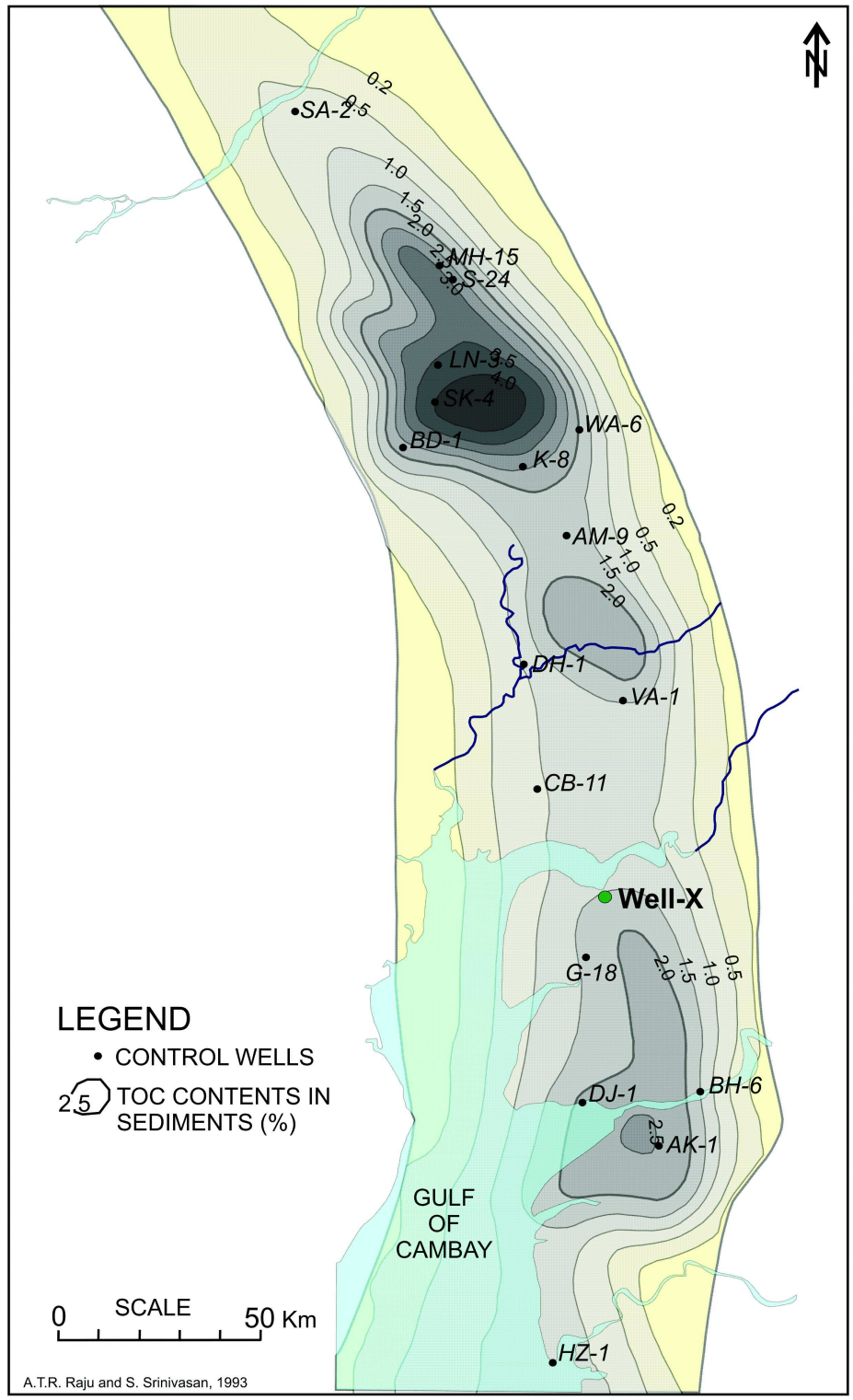

Fig. 4: Total Organic Carbon (TOC) map of Cambay Shale. TOC is higher in North Cambay basin (4-5wt\%) as compared to the South Cambay basin $(1-3 w t \%)$

0.6-1.2\%. Tmax varies in the range of $427-475^{\circ} \mathrm{C}$. It is expected that the lower part of Cambay Shale in the deeper basinal part might have entered to wet/ dry gas window.

Petroleum System modelling has brought out four Source Rocks (SR I to SR IV) spreading primarily over Paleogene to early Eocene with SR IV within middle Eocene. The SR I of Danian age and SR II of Ypresian age are characterized by high TOC (3.5wt\%) with original Hydrogen Index (HI) of the order of $200 \mathrm{mg} / \mathrm{g}$ TOC and $290 \mathrm{mg} / \mathrm{g}$ TOC in SR I and SR II respectively. These major two source facies reached more than 50\% of Transformation Ratio (TR) and contributed more than $95 \%$ of the entrapped hydrocarbons. The TOC content of SR III (Ypresian age) and SR IV (Lutetian age) is 3.5wt\% and $2.5 \mathrm{wt} \%$ with HI of $290 \mathrm{mg} / \mathrm{g}$ TOC and $200 \mathrm{mg} / \mathrm{g}$ TOC respectively. The transformation ratios of SR III and SR IV are $30 \%$ and $15 \%$ respectively and might have contributed minimum hydrocarbons to the subbasin. The critical moment of peak hydrocarbon expulsion is around mid-late Miocene. 


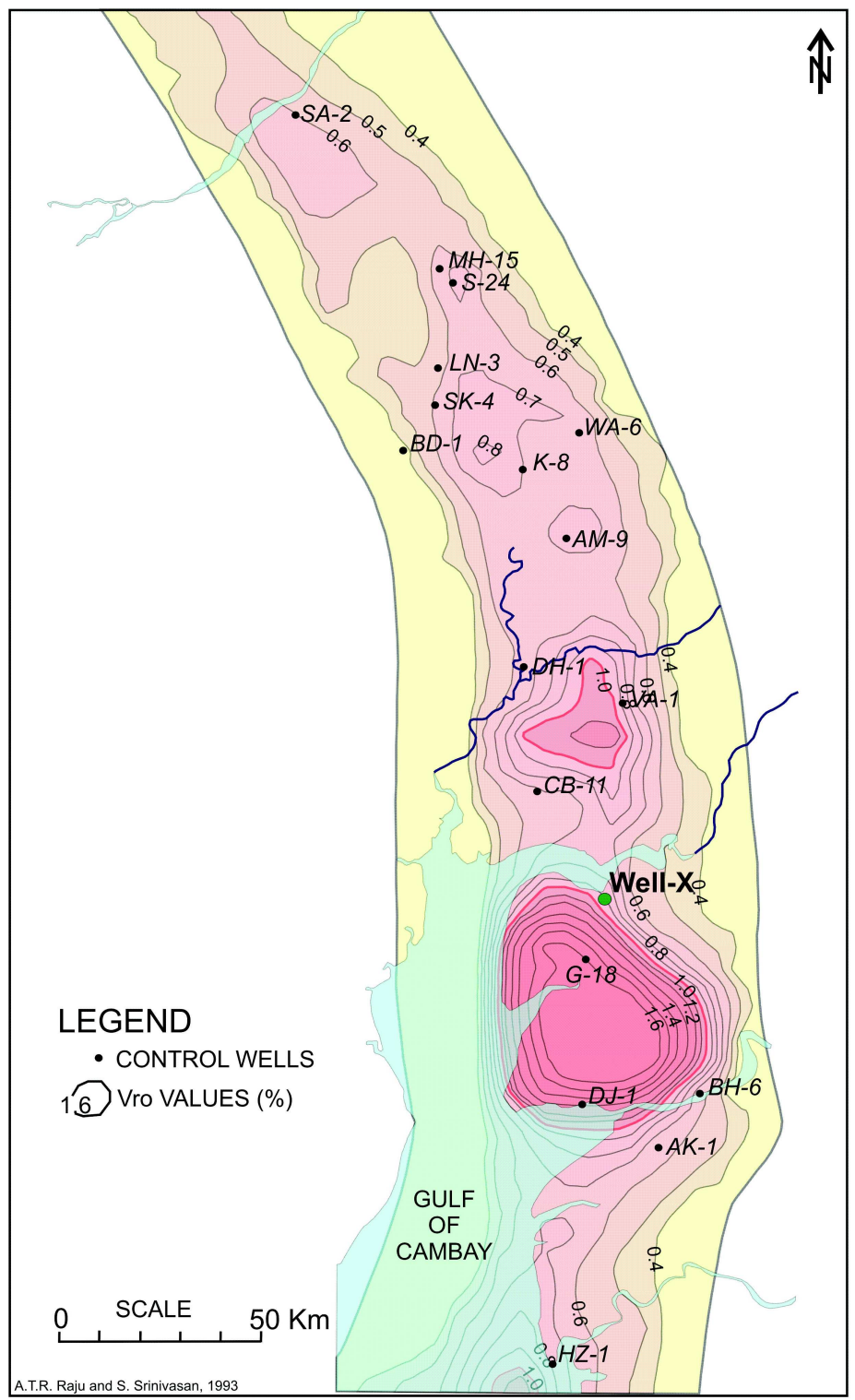

Fig. 5: Thermal maturity map of Cambay Shale. The southern part of Cambay basin exhibits higher maturity (Vitrinite more than 1.2) than the northern part (Vitrinite around 0.8 )

\section{Sequence Stratigraphy and Cyclic fluctuation within Cambay Shale}

Sequence stratigraphy analysis embodies the processresponse dynamics of depositional history and deciphers zones within shale sequence related to more anoxic condition. It further helps in understanding the probable interval of better brittleness (shallowing up sequence) for effective hydrofracturing (Slatt et al., 2010; Slatt, 2013). Stacking of TransgressiveRegressive (T-R) cycles of $3^{\text {rd }}$ order sequence based on gamma log has been analysed within the Cambay Shale section in the Well-X.
The sequence stratigraphy of Cambay basin comprises three $1^{\text {st }}$ order sequences corresponding to the late Cretaceous, the Paleocene rift and early Eocene to Recent Rift Fill/Passive margin phases. Broadly in regional scale plate tectonics, these correspond to the tectonic events of separation of Seychelles from India (K-T boundary) and soft collision of Indian plate with Eurasian plate during early Eocene. Further based on the intra-basin tectonics, four $2^{\text {nd }}$ order sequences have been identified corresponding to early Eocene, late Eocene and late Miocene. 
The boundary between Paleocene and early Eocene in Cambay Basin is marked by a hiatus of approximately 1.0 Ma span and is followed by early Eocene transgression. Based on the palynological data and sharp erosive base inferred from Gamma log, the Paleocene and early Eocene boundary is inferred close to $3225 \mathrm{~m}$ in the Well-X. The Full Bore Formation Micro-Imager (FMI) log infers yellow pattern in tadpole distribution around $3225 \mathrm{~m}$ indicating probable unconformity boundary on top of Paleocene. The early Eocene and middle Eocene boundary in the Cambay Basin is marked by a hiatus of approximately $2.0 \mathrm{Ma}$. Presence of pyritic gastropods and Ostracod: Alcopocythere and Cytheredelle infers the marginal marine influence during deposition and Palynoflora assemblages indicate broadly subtidal-supratidal to coastal environment.

Upward deepening (fining upward) and upward shallowing (coarsening upward) events have been deciphered from Gamma log within the Cambay Shale.The concentration and preservation of organic matter increase in base level of transgressive phase.

The following salient inferences have been drawn on attempting one-dimensional sequence stratigraphy ( $3^{\text {rd }}$ Order), based on T-R cycle, within Cambay Shale of Paleocene to early Eocene in Well$X$ (Fig. 6). The upward shallowing (coarsening upward) boundaries related to envisaged drop in base level are fairly correlated with low Gamma, increase in resistivity and density. The cyclic fluctuations within the shale deposition exhibit vertico-lateral changes and evidence of more anoxic condition is depicted with initial transgression. The Transgressive System Tracts (TST) of bottom most cycle (Cycle-1) is thin over the base of the Transgressive Surface of Erosion on top of Paleocene. Cycle-1 is characterized by claystone, shale and siltstone. TOC is around $1.5-2.0 \mathrm{wt} \%$ and the average vitrinite is 0.9 . The interval of hydrofracturing that yielded oil falls in the upper part of blocky to coarsening stack portion (High System Tracts, HST) of Cycle-4 and the bottom part of TST (Cycle-5). Cycles-5 appears to be characterized by higher TOC (>3.0wt\%). The core CC-4 cut in TST of Cycle-5 is characterized by carbonaceous fissile shale along with some micro fractures. The total gas content of CC-4 varies from 0.989 to $1.882 \mathrm{scc} / \mathrm{gm}$ and storage capacity (in situ) is $2.5 \mathrm{scc} / \mathrm{gm}$. Towards

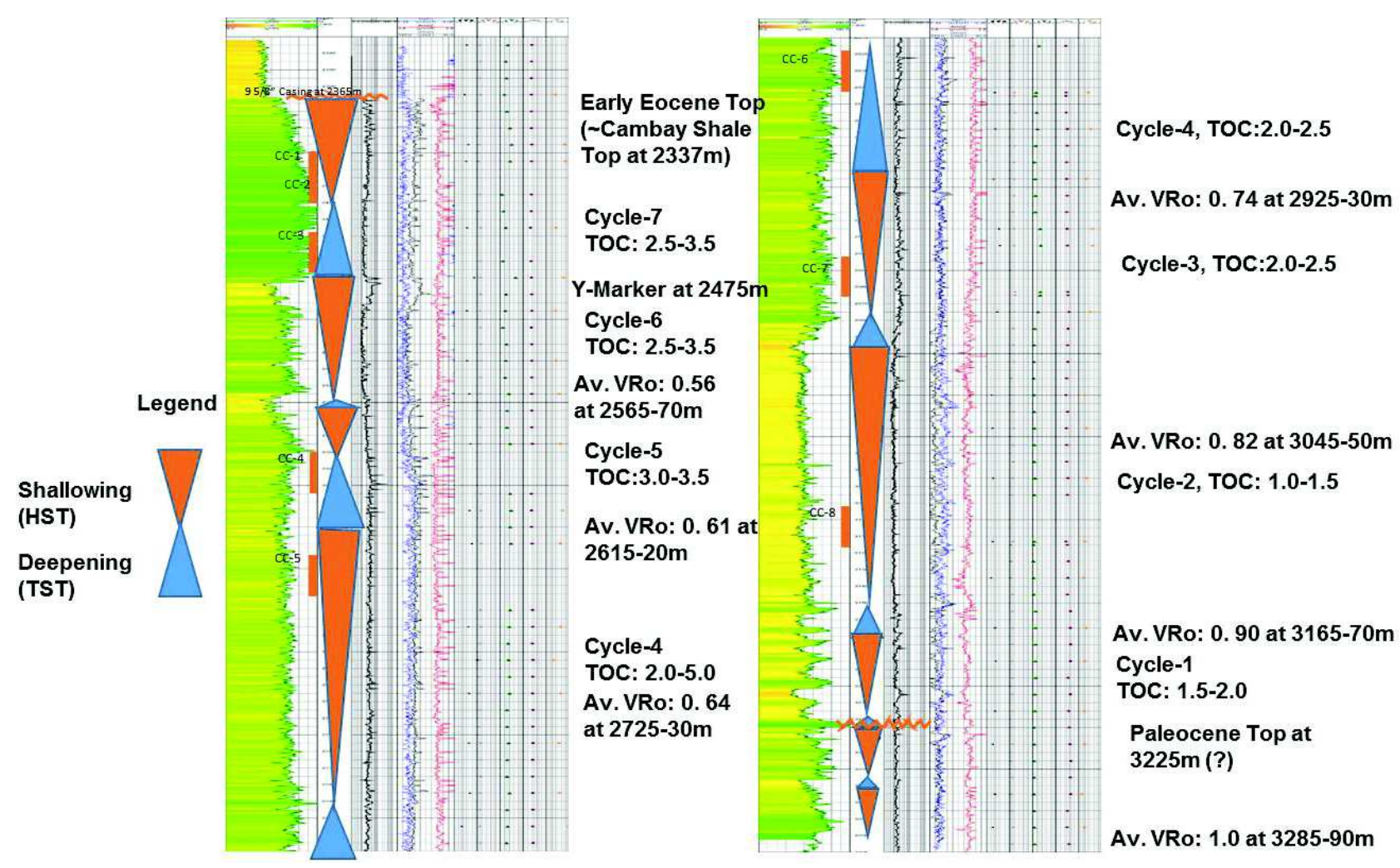

Fig. 6: T-R cycle $\left(3^{\text {rd }}\right.$ Order $)$ within Paleocene-early Eocene section in Well-X with Vitrinite and TOC distribution 
top of Cambay Shale, Cycle-6 and Cycle-7 are characterized by high value of gamma (120-130 API) having TOC value of $3.5 \mathrm{wt} \%$ and VRo of around 0.55 .

Broadly the concept of TR cycles within Cambay Shale and its extension has been preliminary established in couple of other wells drilled for shale oil exploration.

The shale specific studies related to sedimentological, geochemical, petrophysical and geomechanical analysis have been carried out on the extensive cores for shale oil evaluation in the Well-X. The salient interpretation in the zone of interest which yielded oil on hydrofracturing has been briefly enumerated below.

\section{Sedimentological Characteristics}

The shale is deposited under marginal marine (subtidal-coastal) to shoreface deposit. The shale is light to dark grey, moderately indurated and moderately fissile, non-calcareous with thin intercalation of silt and carbonaceous matters (Figs. 7 and 8). Siderite nodules with presence of pyrite are often present.
The fractures in shale are oblique in nature and at places filled with secondary minerals (Fig. 9). The shale is characterized by clay rich matrix and carbonaceous materials and is associated with pores filled with organic matter as observed in SEM analysis (Fig. 9). Presence of pyrite framboids infers anoxic condition of deposition. Predominant clays are kaolinite (around 38\%) and chamosite (around 18\%). Average quartz content $29 \%$ with maximum of $47 \%$. The quartz content increases the brittleness of the shale and facilitates for hydrofracturing.

\section{Geochemical Studies}

Rock-Eval study (Fig. 10) shows TOC content of the Cambay Shale section varies from 2 to 4 wt $\%$ and at places goes upto $5 \mathrm{wt} \%$ with multiple zones of organic rich source facies. Hydrogen Index (HI) in the zone of interest is more than $150 \mathrm{mg} / \mathrm{g}$ TOC.

Frequent gas shows were observed during drilling in Cambay Shale section. Presence of higher hydrocarbons in mud gas collected during drilling infers presence of oil. Sporadic presence of fluorescence with positive cut have also been seen as an indicator of presence of oil. Maximum $4.5 \%$ of gas has been
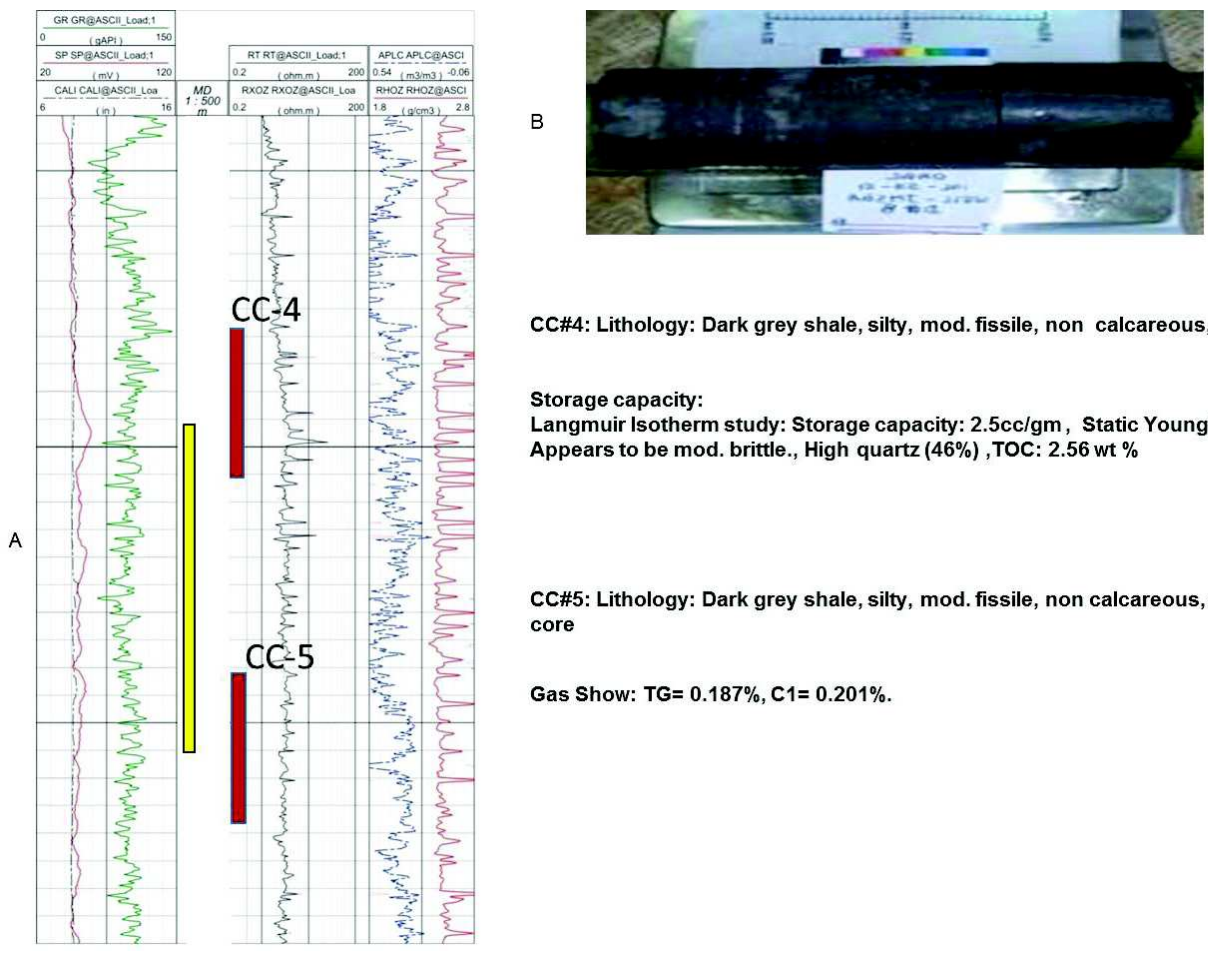

CC\#4: Lithology: Dark grey shale, silty, mod. fissile, non calcareous, sideritic, fractured.

Storage capacity:

Langmuir Isotherm study: Storage capacity: $2.5 \mathrm{cc} / \mathrm{gm}$, Static Young's Modulus: 6694 Mpa, Poisson's Ratio: 0.17 Appears to be mod. brittle., High quartz (46\%), TOC: 2.56 wt \%

CC\#5: Lithology: Dark grey shale, silty, mod. fissile, non calcareous, sideritic, fractured and Gas show observed in core

Gas Show: $\mathrm{TG}=0.187 \%, \mathrm{C} 1=0.201 \%$.

Fig. 7: A: Log chracteristics of the hydrofractured zone (shown in yellow bar) in Well-X, B: A piece of core from the zone which on hydrofracturing yielded oil 

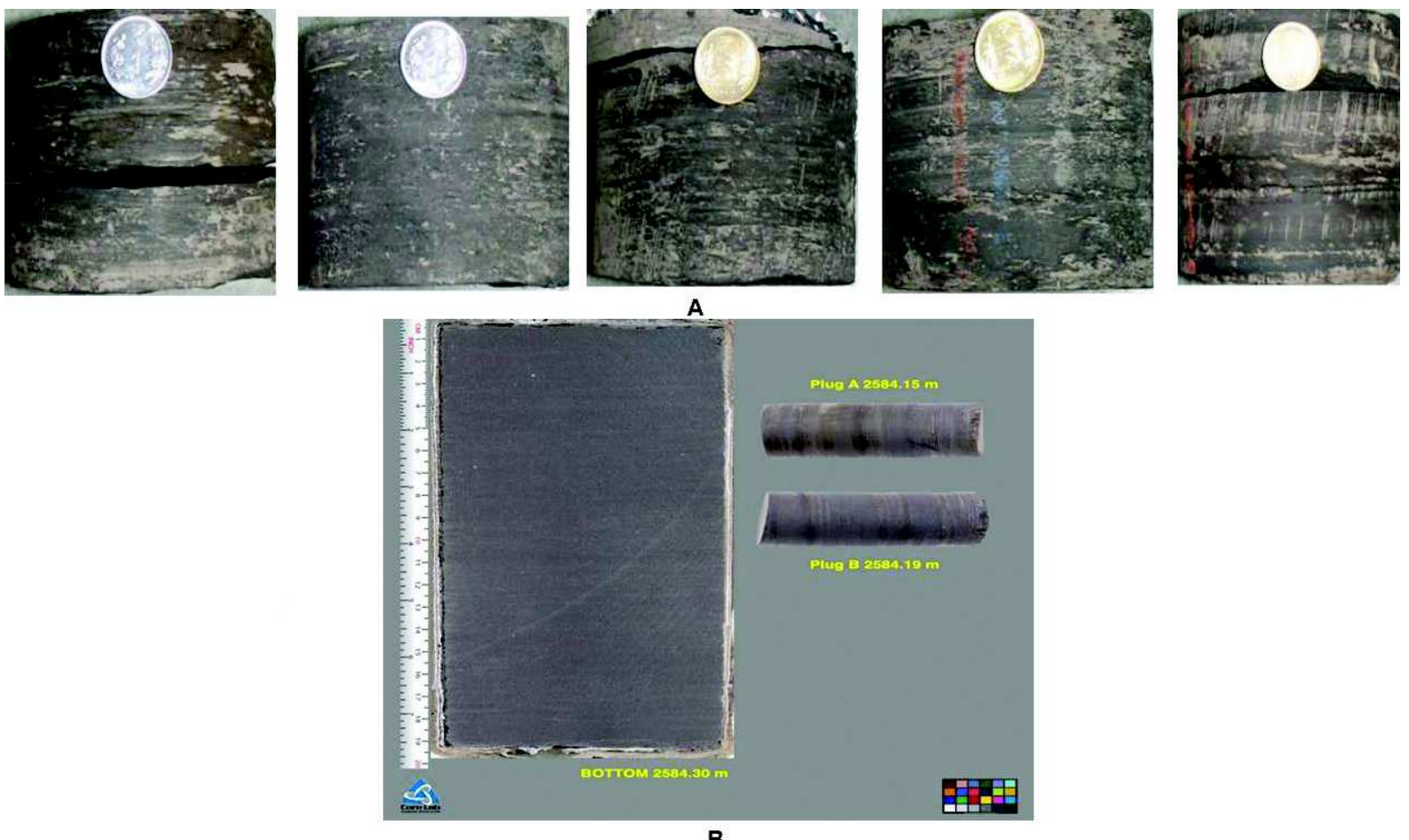

Fig. 8: A: The Cambay Shale in Well-X show presence of thin intercalations of silt and carbonaceous matters and B: Computed Tomography Scan depicts silty nature of shale

A
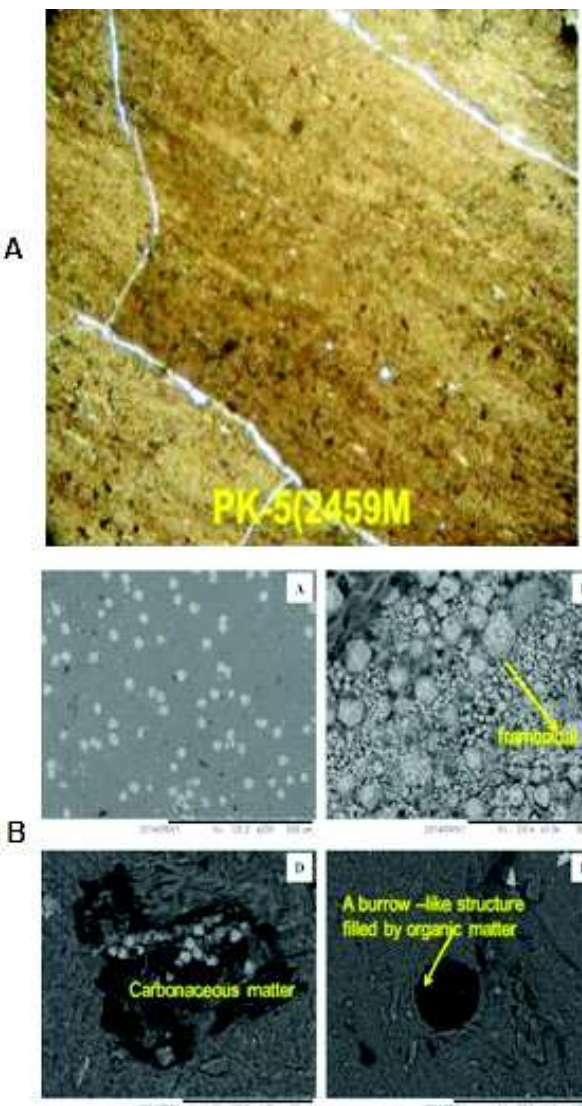
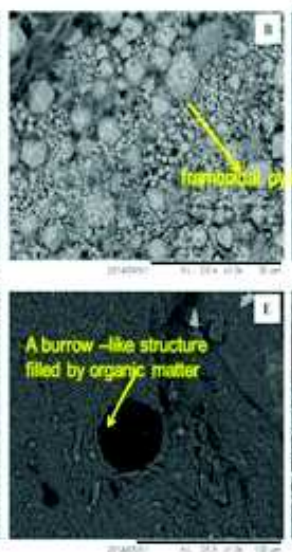
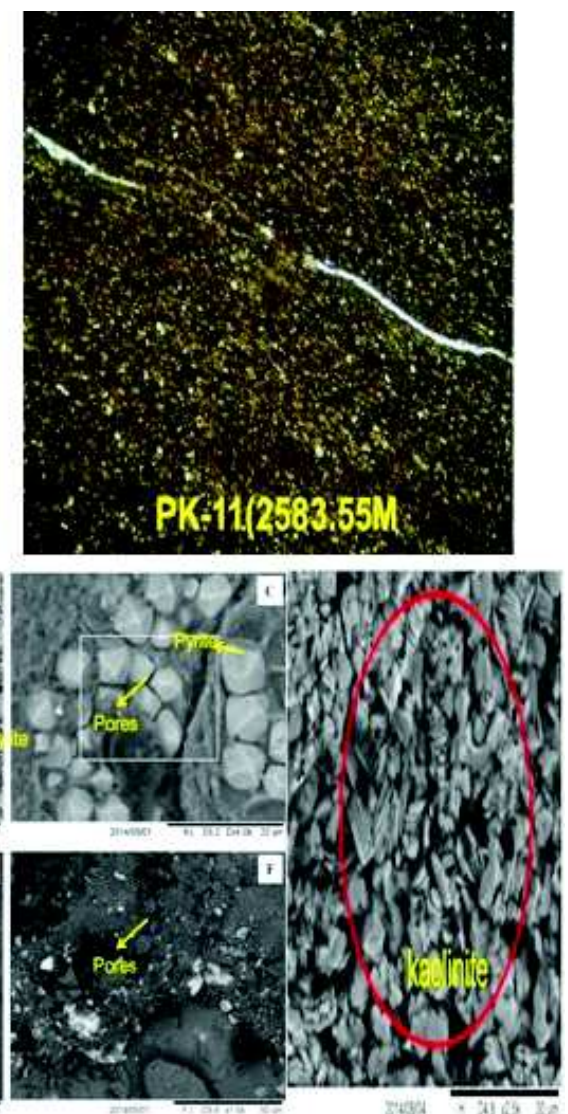

Fig. 9: A: Photomicrograph shows presence of micro-fractures in the core in Cambay Shale and B: SEM study shows presence of carbonaceous matter, organic matter, framboidal pyritites and Kaolinite 


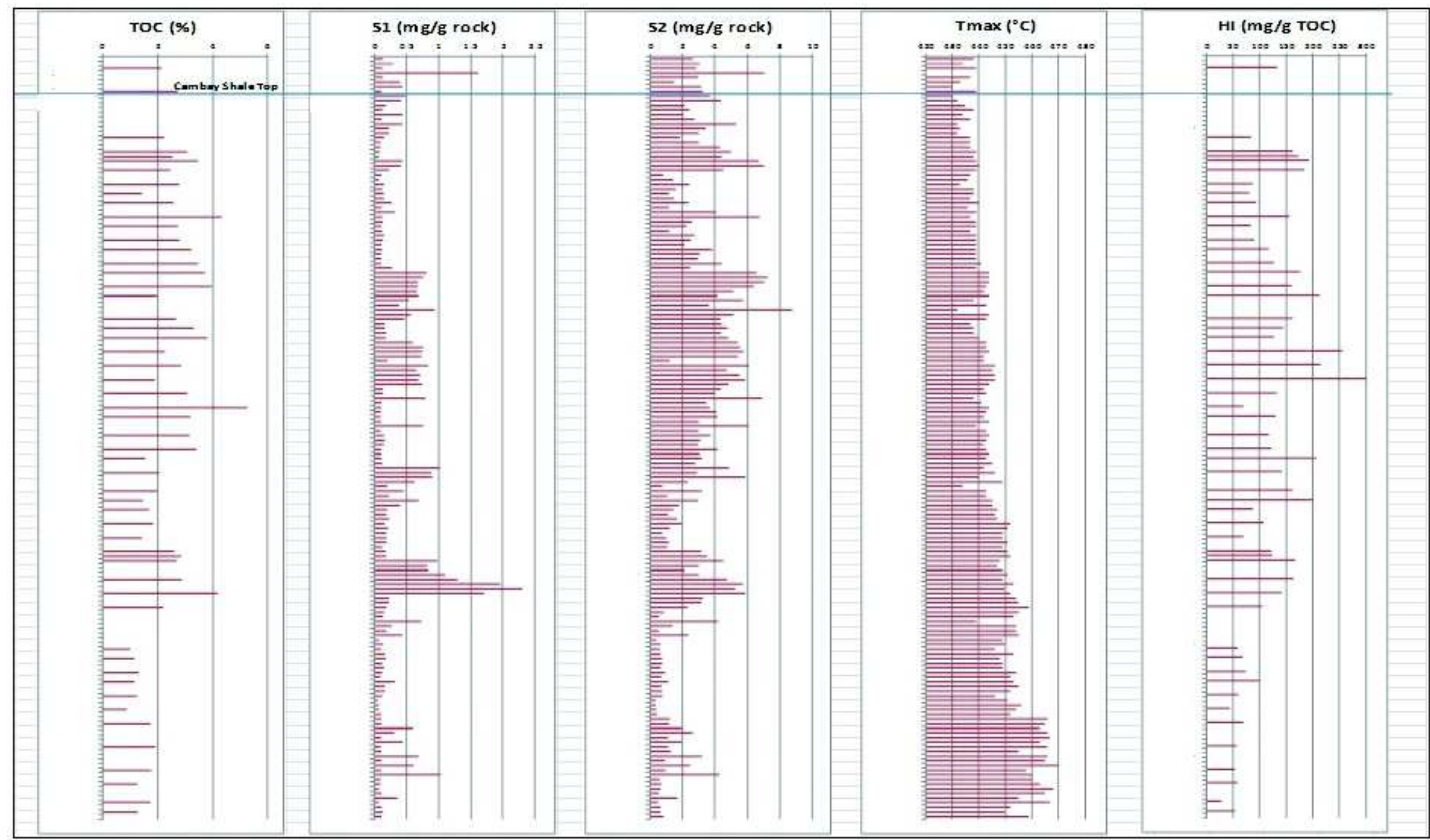

Fig. 10: Geochemical log of Well-X showing TOC, S1, S2, Tmax and HI of Cambay Shale section. Average TOC content is more than 2wt\% and decreases towards deeper depth 
observed in Mud Log within the zone of hydrofractured interval.

The total organic carbon in the interval ranges from $1.08-4.37 \mathrm{wt} \%$ with average more than $2 \mathrm{wt} \%$. Average vitrinite value is 1.0 at $3290 \mathrm{~m}$. The API gravity of oil is 40.0 with wax content around $23 \%$. The shale oil is aliphatic in nature. Abundance of higher n-alkanes $\left(\mathrm{C}_{21}-\mathrm{C}_{31}\right)$, high Pristane to Phytane ratio (6.74-7.78) and Cmax of 27 suggest that the oil is sourced mainly from terrestrial organic matter. Presence of oleanane is often observed in oil and core extracts inferring contribution from angiosperms (flowering plants). The average desorption gas in the zone of interest is of the order of $1.7 \mathrm{scc} / \mathrm{g}$ with storage capacity of the order of $2.5 \mathrm{scc} / \mathrm{g}$. Within Cambay Shale desorption gas in core samples ranges from 0.782 to $5.031 \mathrm{scc} / \mathrm{g}$ with average gas content of $1.96 \mathrm{scc} / \mathrm{g}$. Adsorption isotherm analysis indicates fair degree of gas storage capacity (2.3 to $3.14 \mathrm{scc} /$ g).
The elemental analysis infers the depositional condition, and presence of TOC is closely associated with specific trace elements namely $\mathrm{Ba}, \mathrm{Co}, \mathrm{Cu}, \mathrm{Mo}$, $\mathrm{Ni}, \mathrm{U}, \mathrm{V}$ Zn and oxide of iron (Sano et al., 2013). Oxides of major elements (XRF analysis) present in Cambay Shale are $\mathrm{SiO}_{2}, \mathrm{TiO}_{2}, \mathrm{Al}_{2} \mathrm{O}_{3}, \mathrm{Fe}_{2} \mathrm{O}_{3}, \mathrm{MnO}$, $\mathrm{MgO}, \mathrm{CaO}, \mathrm{K}_{2} \mathrm{O}, \mathrm{P}_{2} \mathrm{O}_{5}, \mathrm{SO}_{3}, \mathrm{Cl}$ along with trace elements viz., Vanadium, Nickel, Gallium, Thorium, Zinc, Copper, Barium etc. With limited data from the well, $\mathrm{SiO}_{2} / \mathrm{Al}_{2} \mathrm{O}_{3}$ ratio (2.42) infers a fair degree of brittleness within the zone of interest.

\section{Petrophysical Analysis}

The Cambay Shale is characterized by relatively high porosity (average: $12.5 \%$ ) and low permeability ranging from 3.7 to 20 nanodarcy. The pores are mainly of interparticle type with small portion related to organic matter. Low matrix permeability could be attributed to high clay content.Connate water saturation in Cambay Shale (average 80\%) is strikingly high and

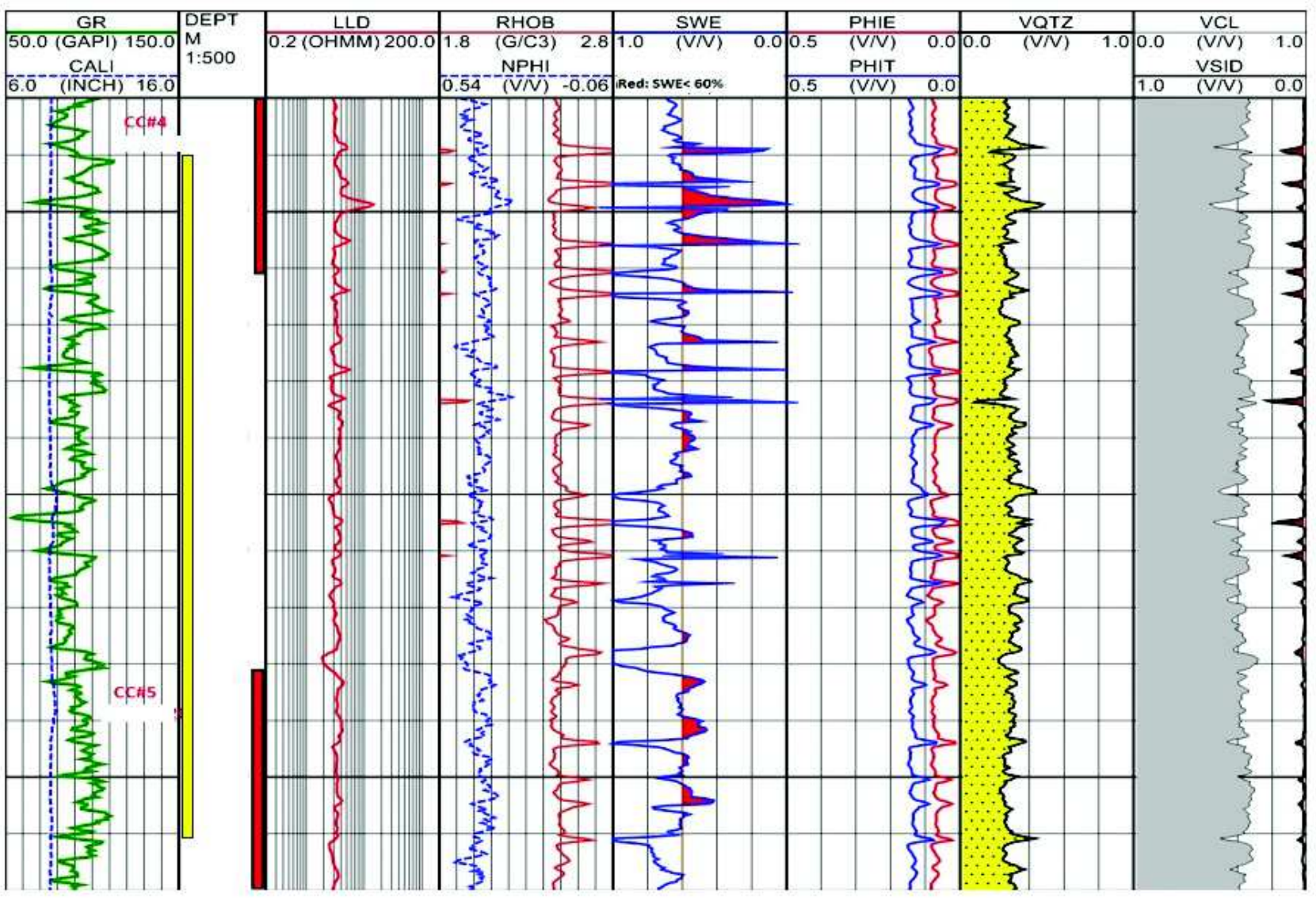

Fig. 11: Log characteristics of part of Cambay Shale section in the interval of Hydrofractured zone (shown in yellow bar) of Well-X. The resistivity is around 3-4 ohm-m with high clay content of around $80 \%$ ( depicted in gray). Quartz content is $\mathbf{1 5 - 2 0 \%}$ (depicted in yellow). Presence of sideritic streaks are observed towards upper part 


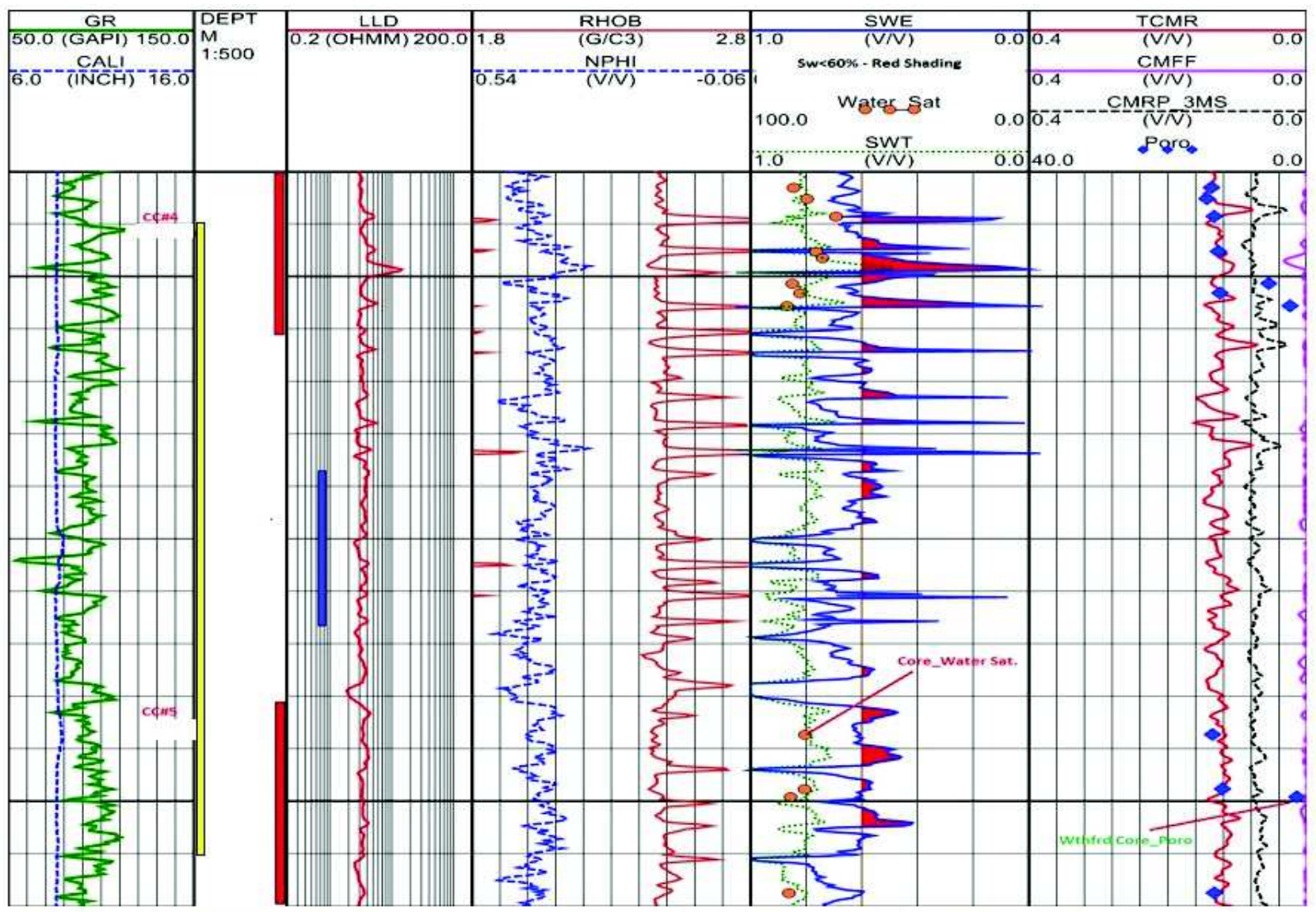

Fig. 12: Log characteristics of part of Cambay Shale section in the interval of Hydrofractured zone (shown in yellow bar) of Well-X. The log depicts high water saturation. Water saturation less than $60 \%$ is shaded red. Log shows close similarity between core and $\log$ derived porosities

envisaged to be of irreducible in nature. In general, based on the log correlation, the Younger Cambay Shale is characterized by high gamma and relatively high TOC content. The Gamma value in the Younger Cambay Shale is of the order of 110 API where as in the Older Cambay Shale it around 90 API. Resistivity of the shale is around 1.5 to $4.0 \mathrm{ohm}-\mathrm{m}$.

The zone of interest is characterized by low resistivity (2-4 ohm-m) with siderite streaks (Fig. 11) present at places inferring oxidizing environment. The total organic carbon in the zone of interest ranges from $0.65-4.37 \mathrm{wt} \%$ with average of $2.4 \mathrm{wt} \%$. The clay (Chlorite and Kaolinite) content is around $40 \%$ with quartz content of approximately $34 \%$. Based on the wireline logs and other data, a zone of $60 \mathrm{~m}$ was hydrofractured and it yielded oil (API gravity $=40.0$ ) with wax content around $23 \%$.

The average core derived porosity is $11.2 \%$ in the zone of interest. The shale is characterized by low permeability, average of the order of 12 nanodarcy (core based). Core derived average gas filled porosity is of the order of $2.03 \%$ in Cambay Shale $(1.8 \%$ within the zone of interest). Maximum core based oil saturation is $7.2 \%$ (Average 3.0 within zone of interest) and maximum gas saturation is $23.5 \%$ (Average:15.8\% in the zone of interest). The log characteristics show close similarity between log derived and core based porosities (Fig. 12). The high water saturation is attributed to complex pore geometries of high clay rich sediment.The Petrtrophysical, geomechanical and geochemical characteristics in the oil bearing zone are depicted in Fig. 13.

Total Organic Content (TOC) has definite relationship with various parameters such as porosity, gas-filled porosity, permeability and water saturation 


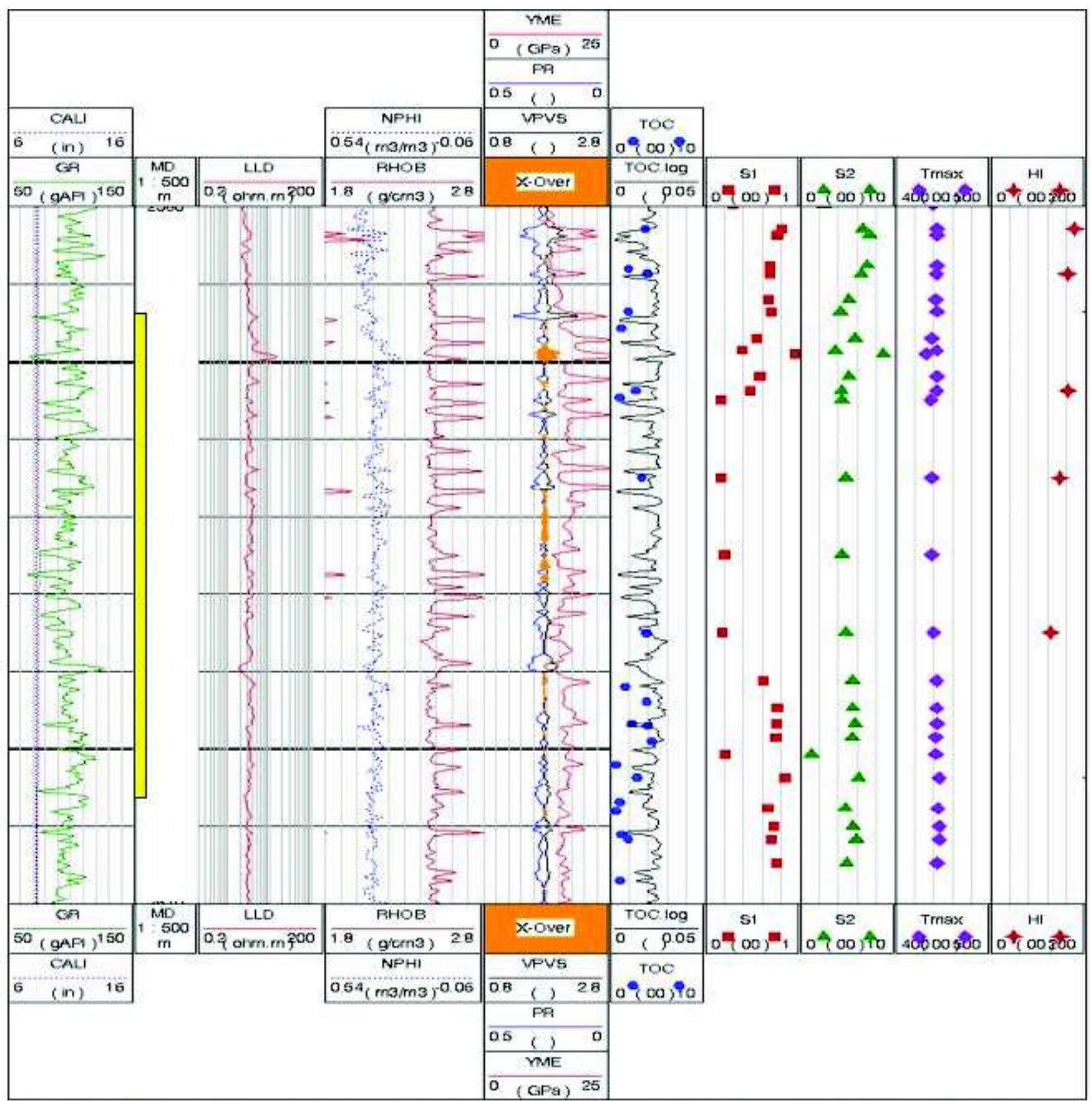

Fig. 13: Geochemical (Rock-Eval data) with core and log derived TOC and Geomechanical characteristics (Young's Modulus and Poisson's Ratio) of part of Cambay Shale section in the interval of Hydrofractured zone (shown in yellow bar) of Well-X

(Wang et al., 2013). An attempt has been made to derive the correlation of TOC with other parameters in Well-X (Fig. 14) based of limited core derived data.It is observed that TOC increases with total porosity, permeability, gas-filled porosity (total porosity times gas saturation) and gas saturation. Water saturation decreases with increase in TOC. Gas filled porosity shows an increase tendency with permeability.

\section{Geomechanical Studies and Hydrofracture}

Core based geomechanical properties, triaxial compressive strength Cambay Shale have been studied. Young's modulus value derived from core ranges from 6133-6694 MPa and Poisson's ratio is of the order of 0.17-0.19.The Minifrac was carried out with $\mathrm{KCl}$ solution to generate data to fine tune the 
960

P K Padhy et al.
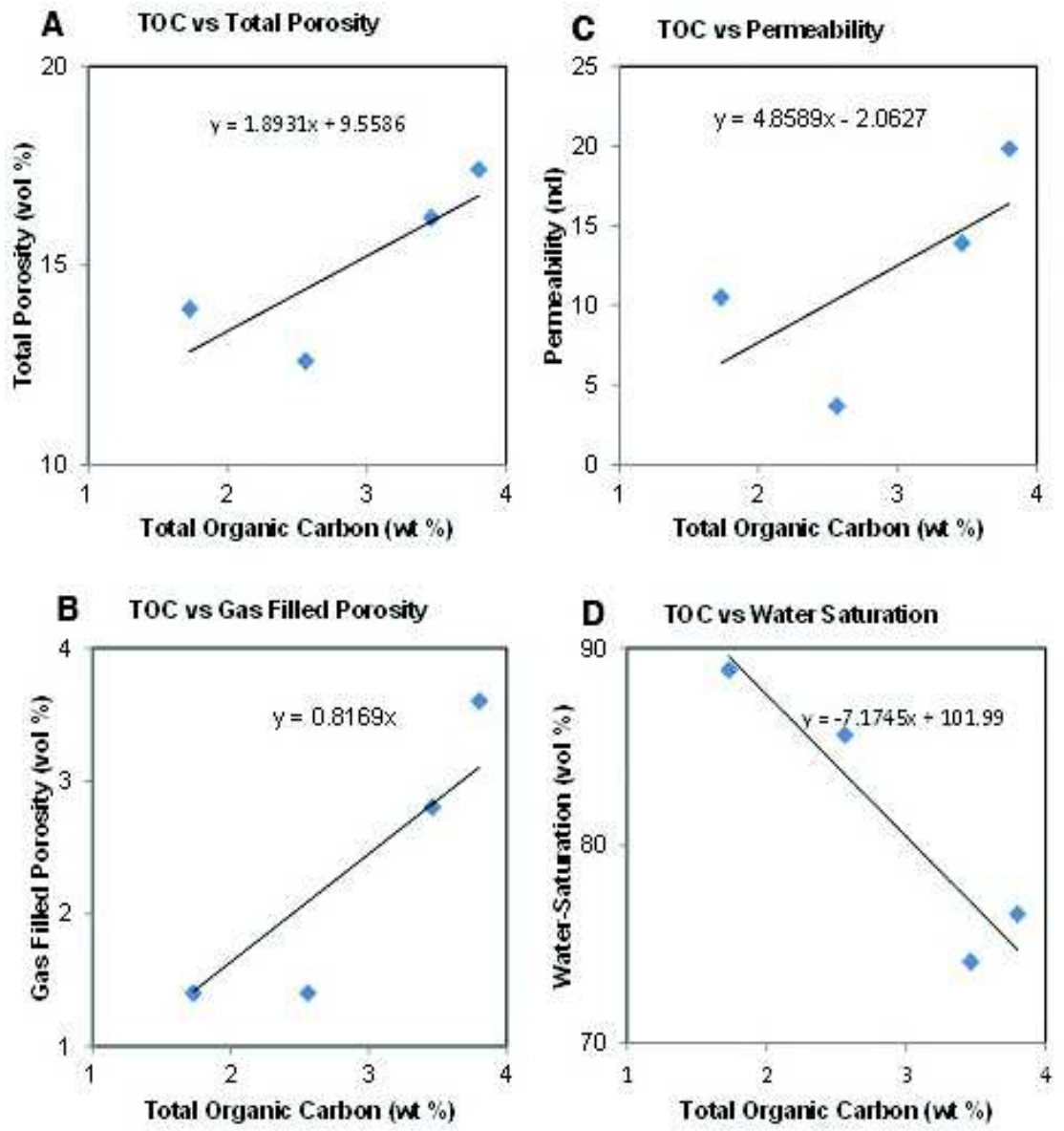
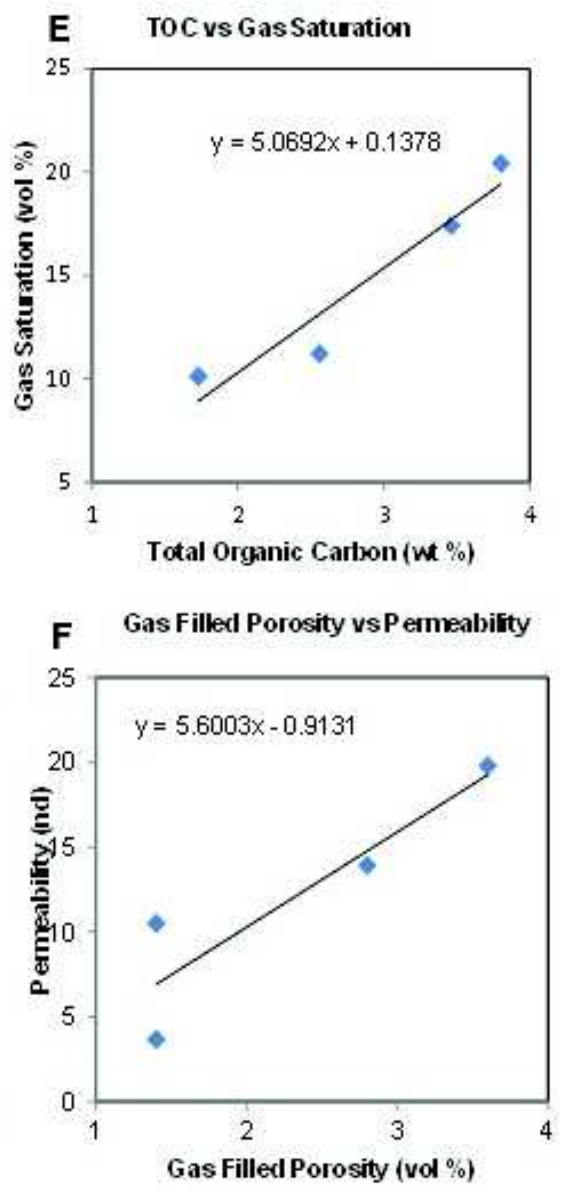

Fig. 14: Plots of total organic carbon vs (A) Total porosity, (B) Gas filled porosity, (C) Permeability, (D) Water saturation and (E) Gas saturation. Gas filled porosity increases with permeability as shown in (F)

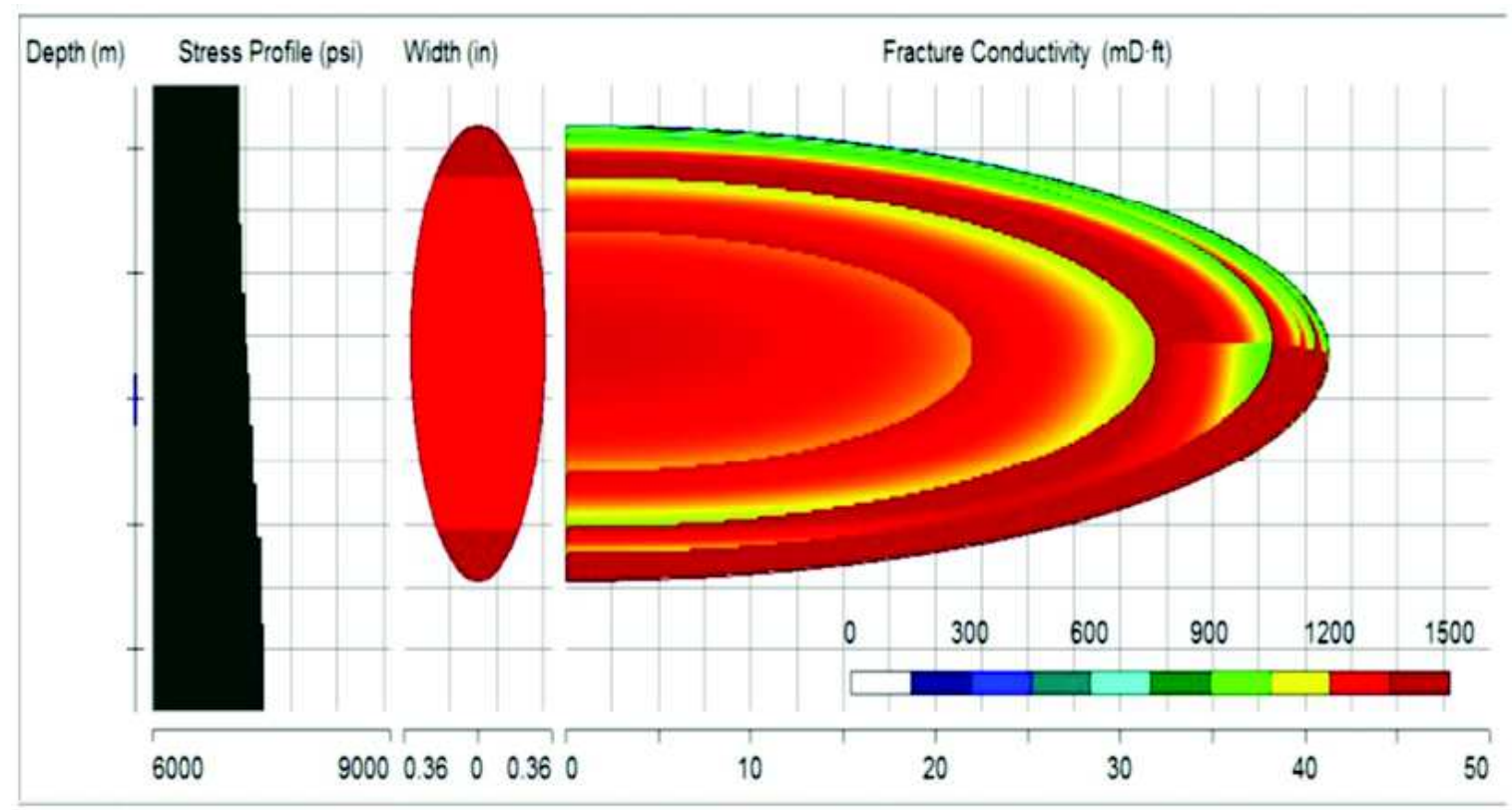

Fig. 15: Fracture profile and conductivity in Well-X. The well Hydrofractured with cross- linked gel fluid. Proppant: 27ton, Pumping rate: $14.5 \mathrm{bpm}$ with concentration of 1.5ppg. Pumping pressure: 6000 Psi. Fracture upper height: 27.1m, Fracture lower height: $41.0 \mathrm{~m}$, Fracture half length: $36.2 \mathrm{~m}$ and average fracture width: 0.95 inch 
final hydrofracture design in the zone of interest. A detail post Minifrac analysis was carried out for friction modeling, estimation of closure pressure, leak-off pattern etc. to make the main job successful. The main hydraulic fracturing job was completed with 27 MT Intermediate Strength Proppant placements inside the formation (Fig. 15). Total pumped gel is approximately $200 \mathrm{~m}^{3}$. Proppant concentration was ramped up from $0.25 \mathrm{ppg}$ to maximum $1.5 \mathrm{ppg}$. The well was activated with CTU on liquid Nitrogen and it yielded waxy oil of $11.32 \mathrm{~m}^{3}$ of oil (API=40.0 with wax content of around 23\%) with a little gas along with flow-back water. It is eveident that the oil retained within the micro fractures, interparticles and organicpore network got connected and stared flowing with enhancement of permeability on hydrofracturing.

\section{Conclusions}

The unconventional hydrocarbon exploration in the Cambay Cenozoic basin has given an initial lead with yielding shale oil and understanding of the prevalence of unconventional petroleum system within Paleocene-early Eocene shale reservoir. For the first time, shale specific integrated data mining and data analysis have been attempted. Broadly the organic matter is of Type III with some input of Type II and TOC is around $2 \mathrm{wt} \%$. The Cambay Shale is deposited in marginal marine (sub-tidal to coastal-shoreface) environment. Occurrence of sideritic nodules are often found indicating oxic depositional condition. The upper part of Cambay Shale is characterized by high uranium content and it decreases rapidly down below. The high uranium content is attributed to more of transitional to marine affinity of depositional condition and presence of pyrite above Y-marker further infers prevalence of anoxic condition with rise in sea level.

As evident from the analysis, the Cambay Shale is rich in clay content (around 55\%) and is characterized by very low permeability. However, the zone hydrfractured is characterized by relatively low

\section{References}

AAPG Bulletin (2007) Special issue Barnett Shale (Eds: Ronald Hill J and Jarvie Daniel M) 91 pp 626

Atkins Laura, Danquah Opuku and Williams Peggy (2011) Global Shale Gas Study Hart Energy Research Group, Hart Energy in clay (around 40\%) and high in quartz content (around 34\%). The sequence analysis within shale section has rendered some interesting observations. The hydrofractured zone that yielded oil falls in the upper part of blocky to coarsening stack portion (HST) of Cycle-4 and the bottom part of TST (Cycle5). The Cycle-5 appears to be characterized by higher TOC (>3.0wt\%). The core CC-4 cut in TST of Cycle5 is characterized by carbonaceous fissile shale along with micro fractures. It has been broadly seen that there has been presence of organic rich matters within TST as inferred from SEM analysis and this has been attributed to anoxic condition. Generally shale deposited within TST is more ductile in nature. The sequence stratigraphic principles help in identifying broader distribution of brittle-ductile couplets based on T-R cycles, thus inferring better fracturable or brittle zone.

The shale oil of the well- $X$ is aliphatic in nature and is sourced from predominantly from terrestrial organic matter. The shale oil and core extracts infer the source rock deposited under more of oxic condition. The hydrocarbon bearing zone within Cambay Shale in the pilot well and its fair degree of spatial extension, based on T-R cycle analysis, have been envisaged on the preliminary study of a couple of wells drilled for shale oil exploration in BroachJambusar block. The integrated geological, geochemical, petrophysical and geomechanical data would help in establishing a viable proposition from techno-economic point of view to usher in a new dimension in alternative fossil fuel prospect in Cambay basin.

\section{Acknowledgements}

Authors are grateful to Director (Exploration) for his encouragement and according permission to publish the paper.We also express our sincere thanks to Shri B S Dhannawat, GGM (Geology) for his encouragement.
Publishing, Houston pp 171

Biswas S K (1982) Rift Basins in western margin of India and their hydrocarbon prospects with special reference to Kutch Basin AAPG Bulletin 66 1497-1513

Cicero, Andrea D and Ingo Steinhoff (2013) Sequence Stratigraphy 
and Depositional Environments of the Haynesville and Bossier Shales, east Texas and North Louisiana, In: AAPG Memoir 105 (Eds: Ursula Hammes and Julia Gale) pp 2546

EIA website, http://www.eia.gov/analysis/studies/ worldshalegas/ (2013) World Shale Gas Resources: An Initial Assessment of 14 Regions Outside the United States

Hart B S (2011) Shale-gas Production and Sequence Stratigraphy: What Makes the Best Part of the Best Plays? Recovery 2011 CSPG CSEG CWLS Convention

Jarvie D M (2012) Shale resources systems for oil and gas, Shale Gas Reservoir-Giant Resources for $21^{\text {st }}$ Century: AAPG Memoir 97, p 1-3

Kumar Arun, Padhy P K and Das Shishir Kumar (2013) Shale gas: Indian scenario and ONGC perspective ONGC Bulletin 48 133-154

Kundu J, Wani M R and Thakur R K ((1993) Structural Style in South Cambay Rift and its Control on Postrift Deltaic Sedimentation In: Proceeding Second Seminar on Petroliferous Basins of India 2 (Eds: Biswas S K, Pandey, Jagdish, Dave Alok, Maithani A, Garg P and Thomas N J ) pp 79-96, Indian Petroleum Publishers, Dehradun

LeFever J A, Martiniuk C D, Dancsok E F R and Lund D F ( 1991) Petroleum potential of the middle member, Bakken Formation, Williston basin, In: Proceedings of the sixth international Williston basin symposium: (Eds: Christopher J E and Haidl F Saskatchewan) Geological Society, Special Publication 11 p 74-94

Mishra Ravi (2008) Shale Gas Exploration in India: Opportunities and Challenges, Abstract vol., GEO India Expo XXI, Noida, New Delhi

Padhy P K and Naik G C (1991) A feasibility study of oil shale exploration in India and its environmental impact, International Conference on "Mineral development and Environment", Abstract vol. p.8, Indian School of Mines, Dhanbad, India

Padhy P K and Singh Daljeet (1998) Geological Petroleum System of Heavy oil occurrences in sedimentary Basins of India, Proceeding Vol. 7 Unitar International conference on Heavy crude and Tar sands, Beijing, China

Padhy P K and Das Shishir Kumar (2013) Shale oil and Gas Plays: Indian sedimentary Basins Geohorizons 18 20-25

Padhy P K, Das Shishir Kumar and Kumar Arun (2013) Krishna Godavari Continental Rift basin and shale gas/Oil Play Systems. In: Proceeding Volume, SPG Conference and Exhibition, Kochi, India
Padhy P K (2016) Shale Gas and Oil Exploration in India: Experience and Challenges, Presented in International Shale Gas \& Oil Workshop 2016, India, 28-29 January, New Delhi

Raju A T R and Srinivasan S (1993) Cambay Basin - Petroleum habitat In: Proceedings of the Second Seminar on Petroliferous Basins of India 2 (Eds: Biswas S K, Alok D, Garg P, Pandey J, Maithani A and Thomas N J) Indian Petroleum Publishers, Dehra Dun, p 33-78

Raju D S N, Peter James, Ravishankar and Kumar Gopendra (2005) An overview of Litho-Bio-Chrono Sequence stratigraphy and sea level changes in Indian sedimentary basins In: APG Special Publication, Allied Printers, Dehradun, pp 210

Rohl H-J, Schimod-Rohl A, Oschmann W, Frimmel A and Schwark L (2011) The Posidonia Shale (Lower Toarchian) of SWGermany: An oxygen-depleted eco-system controlled by sea level and paleoclimate: Paleogeography Paleoclimatology, Paleoecology 165 27-52 doi: 10.1016/ S0031-0182(00)00152-8

Singh P R, Slatt and Coffey W (2008) Barnett Shale-Unfolded: sedimentology, sequence stratigraphy and regional mapping: Gulf Coast Association of Geological Societies Transactions $\mathbf{5 8}$ 777-795

Sano Jennifer L, Ratcliffe Ken T and Spain David R (2013) Chemostratigraphy of the Haynesville Shale In: (Eds: Hammes U and Gale J), Geology of the Haynesville Gas Shale in East Texas and West Louisiana, USA, AAPG Memoir 105 137-154

Sharma S S and Kulkarni P K (2010) Gas Strike in Shale Gas Reservoir in Dholka Field in Cambay Basin, SPE 129082, Proceeding Volume, SPE OGCI

Slatt, Roger M and Rodriguez Norelis D (2010) Comparative Sequence Stratigraphy and Organic Geochemistry of Unconventional Gas Shales: Commonality or Coincidence? AAPG/SEG/SPE/SPWLA Hedberg Research Conference, Critical Assessment of Shale Resource Plays, Dec 5-12, 2010, Austin, Texas, p 5

Slatt, Roger M (2013), Sequence Stratigraphy of the Woodford Shale and Application to Drilling and Production, Search and Discovery Article \#50792

Thakre A N and Padhy P K (1993) Cambay basin architecture and exploration play systems (Abstract) In: Rifting of western margin of India and its bearing on the geological evolution and mineralization, p. 1, Geological Society of India, Annual Convention, M S University, Baroda, India 
USGS (2013) Assessment of Potential Shale Oil and Tight Sandstone Gas Resources of the Assam, Bombay, Cauvery, and Krishna-Godavari Provinces, India, 2013 (http:// pubs.usgs.gov/fs/2013/3113/pdf/fs2013-3113.pdf)
Wang, Fred P, Hammes Ursula and Li Qinghui (2013) Overview of Haynesville Shale Properties and Production In: (Eds: Hammes U and Gale J), Geology of the Haynesville Gas Shale in East Texas and West Louisiana, USA, AAPG Memoir 105, p 137-154. 